\title{
DIFFERENT SOURCES OF INOCULUM TO THE BOKASHI PROVIDES DISTINCT EFFECTS ON THE SOIL QUALITY
}

Juliana Cristina Scotton ${ }^{1}$, Juliana da Silva Pereira ${ }^{1}$, Amália Aparecida Busoni Campos ${ }^{1}$, Diego Fontebasso Pelizari Pinto ${ }^{1,2}$, Wesley Luiz Fialho Costa ${ }^{1}$, Sérgio Kenji Homma ${ }^{1}$

\begin{abstract}
Bokashi soil conditioner aims to assist in the resilience of natural microbiota and its associated functions. Currently, there are several formulations of this conditioner, however, little is known about the influence of the sources of inoculum on its quality. This study objective was to evaluate the effects of different sources of bokashi inoculum on microbiological and physical attributes of the soil. The experiment was conducted in tubes designated as microcosms, incubated at $24^{\circ} \mathrm{C}$ for 32 days, with four treatments and ten replications: C - control; SI - bokashi bran without inoculum; IN1 - bokashi with forest inoculum; IN2 - bokashi with consortium inoculum. The microbiological parameters of colony forming units of fungi and bacteria, microbial biomass carbon, basal soil respiration, metabolic and microbial quotient were evaluated. Among the physical parameters evaluated were dispersed clay, geometric mean diameter (GMD) and organic carbon. The data were submitted to ANOVA and the measurements compared by the Tukey test at $5 \%$. The fungal density was significantly higher for SI and IN1, as compared to the other treatments. In regards to the bacteria, there was an increase for IN1, in comparison with the control. The IN1 treatment demonstrated higher microbial activity and higher carbon uptake in the soil. Regarding the physical attributes, there was greater clay dispersion for IN2 and greater GMD for C. The bokashi formulation with forest inoculum and cropping field provides higher microbiological quality to the soil under controlled conditions.
\end{abstract}

Keywords: organic agriculture, soil conditioner, inoculation.

\section{DIFERENTES FONTES DE INÓCULO DO BOKASHI PROMOVEM EFEITOS DIVERSOS NA QUALIDADE DO SOLO}

\begin{abstract}
RESUMO - O condicionador de solo bokashi possui o objetivo de auxiliar na resiliência da microbiota natural e de suas funções associadas. Atualmente, existem várias formulações de bokashi, no entanto, pouco se sabe sobre a influência das fontes de inóculo na qualidade do mesmo. O objetivo deste trabalho foi avaliar o efeito de diferentes fontes de inóculo do bokashi, nos atributos microbiológicos e físicos do solo, em condições controladas. O experimento foi conduzido em tubos denominados microcosmos, incubados em B.O.D. a $24^{\circ} \mathrm{C}$ por 32 dias, com quatro tratamentos e dez repetições: C - controle; SI - farelos do bokashi sem inóculo; IN1 - bokashi com inóculo de mata; IN2 - bokashi com inóculo de consórcio. Foram avaliados os parâmetros microbiológicos de unidades formadoras de colônia de fungos e bactérias, carbono da biomassa microbiana, respiração basal do solo, quociente metabólico e microbiano. Dentre os parâmetros físicos foram avaliados argila dispersa, diâmetro médio geométrico (DMG) e carbono orgânico. Os dados foram submetidos a ANOVA e as médias comparadas pelo teste de Tukey a 5\%. A densidade de fungos foi maior nos tratamentos SI e IN1, em relação aos demais. Para as bactérias houve aumento para IN1 em relação ao controle. O tratamento IN1 apresentou maior atividade microbiana e maior aporte de carbono no solo. Dentre os parâmetros físicos maior dispersão de argila para o IN2 e maior DMG para C. A formulação de bokashi com inóculo de mata e campo de cultivo proporciona maior qualidade microbiológica ao solo em condições controladas.
\end{abstract}

Palavras-chave: agricultura orgânica, condicionador de solo, inoculação.

\footnotetext{
${ }^{1}$ Centro de Pesquisa Mokiti Okada, Setor de Pesquisa em Manejo de Solo e Planta, juliana.scotton@cpmo.org.br. ${ }^{2}$ Escola Superior de Agricultura Luiz de Queiroz - Universidade de São Paulo, Programa de Pós Graduação Solos e Nutrição de Plantas
} 


\section{INTRODUCTION}

The search for quality food that stimulates human health has increased the demand for products from organic production systems (Dias et al., 2015). Organic agriculture seeks more sustainable alternatives to food production, making the soil the main target. For this agriculture model, the biological processes in soil are crucial to maintaining sustainability (Kaschuk et al., 2010). As such, better usage of these processes is indispensable, and forms the basis for balance of the system and soil resilience. Pristine soils, as in the case of forests, exhibit high microbial and functional diversity (Rodrigues et al., 2013; Paula et al., 2014), which guarantees a more efficient utilization of available resources, such as carbon sequestration and biogeochemical cycling of nutrients.

Within this concept is bokashi, a soil conditioner that originated in Japan in the $19^{\text {th }}$ century (Fundação Mokiti Okada, 2002). This soil conditioner is an organic compound composed of vegetable bran and microbial inoculum, which, when submitted to a controlled fermentation process, results in a product with microorganisms that are capable of aiding in the improvement of soil structure. Therefore, through bioaugmentation (Inoculation of the substrate by previously selected microorganisms) and biostimulation (Stimulation of microorganisms by the addition of nutrients), recovery of natural microbiota is sought as well as a variety of the metabolic functions performed by these microorganisms, which are essential for the processes of plant nutrition and health (Siqueira \& Siqueira, 2013).

Currently, studies involving bokashi have been focusing on plant nutrition (Ferreira et al., 2013), rhizosphere disease control (Duarte et al., 2006) and on the characterization of the fungal microbiota (Magrini et al., 2011). Nevertheless, there are several formulations of bokashi available, about which there is no knowledge regarding the influence of the different inoculum sources on the fermentation process and on the possible improvement of the microbial and physical attributes of the soil. As such, this study objective was to evaluate the effects of different sources of bokashi inoculum on the microbiological and physical attributes of soil, under controlled conditions.

\section{MATERIALAND METHODS}

The experiment was conducted in cylindrical tubes with a known volume of $272 \mathrm{~cm}^{3}$, designated as microcosms. The experiment design was completely randomized, with four treatments and ten replications.

The soil used in the assembly of this experiment was collected at a depth of $0-10 \mathrm{~cm}$ with the aid of a hoe, along the planting row of a conventional citrus orchard; the signalgrass, Brachiaria decumbens, was removed from between the rows of the same orchard. The soil was passed through a sieve with $2 \mathrm{~mm}$ mesh, and the grass dried in a greenhouse at $65^{\circ} \mathrm{C}$ for 24 hours, and then ground up manually and homogenously.

The treatments and their compositions are shown below (Table 1).

The bokashi was prepared with a mixture of 4.0 $\mathrm{kg}$ of rice bran; $3.7 \mathrm{~kg}$ of wheat bran; $2.0 \mathrm{~kg}$ of castor cake; $100 \mathrm{~mL}$ of prebiotic, based on starch and glucose; and $3.5 \mathrm{~L}$ of non-chlorinated water. The ingredients of each batch of bokashi were homogenously mixed and poured out in $20 \mathrm{~cm}$ deep furrows and covered with $80 \%$ shade cloth. The fermentation process occurred over three days and the temperature was monitored, so as to never exceed $50^{\circ} \mathrm{C}$.

The microcosms were assembled in a laminar flow chamber, with the following proportions by mass, $94.4 \%$ of the soil, $3.1 \%$ of the dried brachiaria and $2.5 \%$ of bokashi or bran, in accordance with each treatment. The moisture in the microcosms was standardized with deionized water to $75 \%$ of the field capacity, and maintained throughout the experiment. In order to equalize the conditions between the treatments, after the microcosms were prepared, they were sealed with $80 \%$ shade cloth and immediately inserted into B.O.D. at $4{ }^{\circ} \mathrm{C}$. Upon completion of preparation, the microcosms were randomly arranged and, immediately thereafter, subjected to a gradual increase in temperature until reaching $24{ }^{\circ} \mathrm{C}$, with a relative humidity of $87 \%$ and without photoperiod.

The experiment was evaluated over a period of 32 days after B.O.D. incubation. Fungi and bacteria were quantified using the serial dilution technique, followed by plating in specific culture media; PDA (Potato Dextrose Agar) + chloramphenicol for fungi and PCA (Plate Count Agar) for bacteria, in accordance with the methodology of Moreira \& Siqueira (2006).

For the microbial biomass carbon (MBC) analysis, the procedure proposed by Vance et al. (1987) was used. The fumigated soil samples were incubated for 
Table 1 - Treatments and their respective descriptions

\begin{tabular}{|c|c|c|}
\hline Treatments & Descriptions & Composition of the inoculum \\
\hline Control (C) & $\begin{array}{l}\text { Soil, brachiaria, without addition } \\
\text { of bran or inoculum }\end{array}$ & - \\
\hline Without inoculum (SI) & $\begin{array}{l}\text { Soil, brachiaria, bokashi bran, } \\
\text { without inoculum }\end{array}$ & - \\
\hline Inoculum 1 (IN1) & $\begin{array}{l}\text { Soil, brachiaria, bokashi with } \\
\text { forest inoculum }\end{array}$ & $\begin{array}{l}\text { Collected in cropping field and } \\
\text { Permanent Preservation Area (APP) } \\
\text { and composed of plant litter, transition } \\
\text { zone (area located between plant litter } \\
\text { and soil) and soil, collected at } 0-10 \mathrm{~cm} \text { depth }\end{array}$ \\
\hline Inoculum 2 (IN2) & $\begin{array}{l}\text { Soil, brachiaria, bokashi with } \\
\text { consortium inoculum }\end{array}$ & $\begin{array}{l}\text { Consortium of bacteria and yeasts collected } \\
\text { from several places and environment (soil } \\
\text { and plant). They were isolated based on } \\
\text { plant disease control and mineral solubilizing criteria. }\end{array}$ \\
\hline
\end{tabular}

two days, after which the carbon was extracted from the fumigated and non-fumigated samples, and determined by titration. The determination of carbon was expressed according to the following formula:

$$
\mathrm{MBC}=2,64 \times \mathrm{Ec}
$$

Where:

$2.64=$ correction factor;

$\mathrm{Ec}=$ difference between fumigated and non-fumigated soil.

The basal respiration rate was estimated by the $\mathrm{CO}_{2}$ released from $50 \mathrm{~g}$ of soil during incubation for seven days, and the metabolic quotient was determined through the relationship between basal respiration and microbial biomass carbon (Silva etal., 2007). The microbial quotient was expressed between the carbon ratio of the microbial biomass and the organic carbon (OC), and calculated in accordance with Powlson et al. (1987).

For the determination of soil aggregates, the samples were submitted to the wet sieving process proposed by Kemper \& Chepil (1965). The stability of the aggregates was expressed by the geometric mean diameter (GMD) in accordance with the equation proposed by Mazurak (1950):

$$
G M D=\exp \left[\frac{\sum_{i=1}^{n} w i \log \overline{x l}}{\sum_{i=1}^{n} w i}\right]
$$

Where:

wi $=$ mass of the aggregates retained in each of the sieves of the 5 classes $(\mathrm{g})$;
$\operatorname{Logxi}=$ logarithm of the average diameter of the classes of sieves used ( $\mathrm{mm})$.

The dispersed clay (DC) was determined in accordance with a methodology adapted from Dexter \& Czyz (2000). Basically, $10 \mathrm{~g}$ of soil were weighed and mixed in $100 \mathrm{~mL}$ of deionized water. The samples were agitated in an orbital shaker at $140 \mathrm{rpm}$ for 5 minutes, followed by a resting period of 10 minutes. A $30 \mathrm{~mL}$ aliquot was pipetted in order to achieve a turbidimeter reading. The result was expressed in NTU.g-1 (Nephelometric Turbidity Units).

Data were submitted to the Shapiro-Wilk normality test and those with abnormal distribution were transformed by Box-Cox. Afterwards, they were submitted to variance analysis (ANOVA) and the means were compared by the Tukey test, at $5 \%$ significance.

\section{RESULTS AND DISCUSSION}

Treatments SI and IN1 presented a higher number of fungi when compared to the others. While for the bacteria, only the IN1 treatment showed an increase in the number of CFU about the control group (Table 2).

The addition of organic bran stimulated the growth of fungi for the SI and IN1 treatments, functioning as a pre-biotic. However, for IN2, fungal growth was not different from the control. In relation to the bacteria, only the IN 1 treatment showed a higher number of CFU in comparison to the control group, demonstrating that the type of inoculum was also an important factor for bacterial growth. 
The increase in the number of fungi and bacteria in the soil is beyond the addition of organic materials. The ecological structure of the microbial community of inoculum may be directly associated with these results as it has a direct influence on numerous processes in the soil such as organic material mineralization, nutrient cycling, formation of humus and biological balance, among others (Moreira \& Siqueira, 2006). Thus, the inoculum source is an important factor for the fungi and bacteria increment on soil.

Table 3 shows the data of the indicators of soil quality, demonstrating the differential of the IN1 treatment in three of the four parameters evaluated.

Among the bioindicators of soil quality, there was a significant increase in the microbial biomass carbon (MBC) for the IN1 treatment. The basal respiration of the soil $(\mathrm{C}-\mathrm{CO} 2)$ increased in all treatments to which organic material bran had been added. In regards to the action on the metabolic quotient (qCO2), there was a significant difference between the SI and IN1 treatments, with the latter demonstrating the lower level. However, the microbial quotient (qMIC) presented a greater level in the IN1 treatment.
The results showed that the source of the inoculum was a determining factor in the improvement of the microbiological quality of the soil. Even with the SI presenting similar quantities of fungi and bacteria, an improvement in the evaluated parameters was not guaranteed, as well as with the IN2 which, despite being inoculated, showed no improvement in said parameters.

Higher levels of soil quality bioindicators are observed in forest soil (Kaschuck et al., 2010). The diversity of organic composts from forest plant litter is directly proportional to the plant diversity enabling the coexistence of microbial communities with different nutritional requirements (Moreira et al., 2013). As such, the fact that the IN1 treatment presents greater microbiological quality is closely linked to the composition of the inoculum which, in this case, was composed of three different layers (plant litter, transition zone and soil) of one APP and cropping field. Furthermore, there had been no selection of specific microbial groups resulted in the preservation of pre-existing ecological relationships within the soil, which fostered better usage of the available nutrients.

Table 2 - Averages for fungi and bacteria in the soil (CFU.g-1 soil)

\begin{tabular}{lcc}
\hline Treatment & Fungi & Bacteria \\
\cline { 2 - 3 } & $\left(\right.$ CFU x 10 $\mathrm{g}^{-1}$ soil $)$ & $\left(\right.$ CFU x 10 $\mathrm{g}^{-1}$ soil $)$ \\
\hline C & $4.38 \mathrm{~b}$ & $3.79 \mathrm{~b}$ \\
SI & $10.51 \mathrm{a}$ & $5.01 \mathrm{ab}$ \\
IN1 & $10.88 \mathrm{a}$ & $8.16 \mathrm{a}$ \\
IN2 & $2.35 \mathrm{~b}$ & $5.16 \mathrm{ab}$ \\
CV\% & 25.45 & 33.69 \\
\hline
\end{tabular}

$\mathrm{C}=$ control; $\mathrm{SI}=$ without inoculum; IN1 = Inoculum 1; IN2 = Inoculum 2 . Averages in the column, followed by the same letter, do not differ statistically among themselves $(\mathrm{P}>0.05)$ by Tukey test. The data were processed by Box-Cox.

Table 3 - Average of the microbial biomass carbon (MBC), basal respiration of the soil (C-CO2), metabolic quotient (qCO2) and microbial quotient (qMIC)

\begin{tabular}{|c|c|c|c|c|}
\hline Treatment & $\mathrm{MBC}$ & $\mathrm{C}-\mathrm{CO}_{2}$ & $\mathrm{qCO}_{2}$ & qMIC \\
\hline & (mg C kg ${ }^{-1}$ soil) & $\left(\mathrm{mg} \mathrm{C}-\mathrm{CO}_{2} / \mathrm{kg}^{-1}\right.$ soil day $\left.{ }^{-1}\right)$ & $\left(\mathrm{mgC}-\mathrm{CO}_{2} \cdot \mathrm{g}^{-1} / \mathrm{BMS}-\mathrm{C} \cdot \mathrm{day}^{-1}\right)$ & $(\%)$ \\
\hline $\mathrm{C}$ & $821.08 \mathrm{~b}$ & $99.27 \mathrm{~b}$ & $0.13 \mathrm{ab}$ & $2.90 \mathrm{~b}$ \\
\hline SI & $913.30 \mathrm{~b}$ & $133.14 \mathrm{a}$ & $0.15 \mathrm{a}$ & $2.88 \mathrm{~b}$ \\
\hline IN1 & $1,238.98 \mathrm{a}$ & $132.75 \mathrm{a}$ & $0.11 \mathrm{~b}$ & $3.93 \mathrm{a}$ \\
\hline IN2 & $927.40 \mathrm{~b}$ & $125.61 \mathrm{a}$ & $0.14 \mathrm{ab}$ & $3.06 \mathrm{~b}$ \\
\hline $\mathrm{CV} \%$ & 12.57 & 32.16 & 25.54 & 14.26 \\
\hline
\end{tabular}

$\mathrm{C}=$ control; $\mathrm{SI}=$ without inoculum; IN1 = Inoculum $1 ; \mathrm{IN} 2=$ Inoculum 2 . Averages in the column, followed by the same letter, do not differ statistically among themselves $(\mathrm{P}>0.05)$ by Tukey test. The C-CO2 data were processed by Box-Cox. 
Despite this, upon evaluating the growth of green onions and cilantro using bokashi inoculated with fermented milk, Mota (2013) observed a significant increase in the $\mathrm{MBC}$, suggesting that the conditioner provides a stimulus to soil microbiota.

The increase in basal respiration $(\mathrm{C}-\mathrm{CO} 2)$ as of the addition of bran material had been anticipated as it is a source of nutrients for the micro-organisms, which in turn favors the microbial activity. A similar result was found by Poças et al. (2009) who, upon adding different organic materials to the soil, verified an increase in basal respiration.

The metabolic quotient (qCO2) showed that the IN1 presented lower losses of $\mathrm{CO} 2$ per unit of biomass in relation to the SI, being more efficient in the conversion of organic material in soil microbial biomass. This index expresses the efficiency substrate usage by the soil microrganisms and lower values demonstrate greater efficiency (Anderson \& Domsch, 1993).

The microbial quotient provides clues about the quality of organic matter, and shows that the IN1 treatment demonstrated a greater ability to utilize the organic material added, i.e. it managed to convert more readily assimilable carbon into microbial biomass, culminating in a greater increase of carbon in the soil. According to Sampaio et al. (2008), the higher the value of this index, the greater input of carbon into the system.

Therefore, the simple biostimulation of soil microbiota with the addition of bran is not sufficient to change the quality standards of the same, which indicates that the composition of the bokashi inoculum is a factor to be considered in order to obtain compost that is able to improve the microbiological quality of the soil.

The results of the clay dispersion, geometric mean diameter and the organic carbon as a function of the treatments are shown in Table 4.

The greatest dispersion of clay particles was observed in the IN2 treatment which had the lowest average GMD. The fact that this treatment contains higher levels of clay dispersion can be associated with the source of the inoculum. Consortium inoculum, despite demonstrating potential in various areas of biotechnology (Pindi \& Satyanarayana, 2012; Mandalaywala \& Trivedi, 2016) does not maintain the original ecological structure, which may result in the rupture of ecosystemic functions
Table 4 - Average values of clay dispersion (CD), geometric mean diameter (GMD) and organic carbon (OC) submitted to different treatments

\begin{tabular}{lccc}
\hline Treatment & $\mathrm{CD}$ & $\mathrm{GMD}$ & $\mathrm{OC}$ \\
\hline & $\left.(\mathrm{NTU} \mathrm{g})^{-1}\right)$ & $(\mathrm{mm})$ & $\mathrm{g}^{-k^{-1}}$ \\
$\mathrm{C}$ & $23.16 \mathrm{~b}$ & $2.45 \mathrm{a}$ & $28.41 \mathrm{c}$ \\
SI & $19.01 \mathrm{~b}$ & $1.70 \mathrm{~b}$ & $31.79 \mathrm{a}$ \\
$\mathrm{IN} 1$ & $24.64 \mathrm{~b}$ & $1.78 \mathrm{~b}$ & $31.53 \mathrm{ab}$ \\
$\mathrm{IN} 2$ & $44.46 \mathrm{a}$ & $1.60 \mathrm{~b}$ & $30.25 \mathrm{~b}$ \\
$\mathrm{CV} \%$ & 3.90 & 25.45 & 3.64 \\
\hline
\end{tabular}

$\mathrm{C}=$ control; $\mathrm{SI}=$ without inoculum; $\mathrm{IN} 1=$ Inoculum $1 ; \mathrm{IN} 2=$ Inoculum 2 . Averages in the column, followed by the same letter, do not differ statistically among themselves $(\mathrm{P}>0.05)$ by Tukey test.

that are important when compared with the forest inoculum. Moreover, a smaller amount of fungi was found in this treatment (Table 2), which may have influenced these results.

Soils that are susceptible to dispersion of clay and low stability of aggregates are prone to densification due to clogging of the capillary pores by clay. As a result, the temperature of the soil rises, there is a decrease in the rate of water infiltration and, consequently, restriction of gas exchange between the soil and the atmosphere (Dexter \& Czyz, 2000) which negatively influences soil microbial activity and its processes (Cardoso et al., 2013).

With respect to the GMD, a significant difference in the $\mathrm{C}$ treatment was observed. Included among the numerous factors promoting the aggregation and stabilization of the soil are the exudates of microorganisms, production of fungal mycelium, organic matter content, wetting and drying cycles and the source material of the soil (Moreira \& Siqueira, 2006; Voroney, 2007). The greatest GMD value in the $C$ treatment is not attributed to microbial activity as this was inferior to that found in the other treatments (Table 3 ). The organic carbon (OC) of the soil was statistically lower in $\mathrm{C}$ because there was no addition of soybean meal (Table 4). Therefore, this result is due to the natural densification process of the soil, in comparison to the other treatments which received the organic material. Soils with the same texture present GMD which is close to this level, as demonstrated by Costa Jr. et al. (2012).

As such, the composition of the inoculum, which proved decisive for the changes in the microbiological processes of soil in the short term, did not influence the physical properties of the same. 


\section{CONCLUSIONS}

The source of bokashi's inoculum is a relevant factor for its effect on soil quality. The bokashi made with inoculum collected from soil of cropping area and natural forest provided greater amount of microbial biomass carbon and better efficiency to make available the organic carbon for microrganism in the soil. The bokashi with consortium inoculum showed a higher soil clay dispersion.

\section{CITED LITERATURE}

ANDERSON, T.H.; DOMSCH, K.H. The metabolic quotient for $\mathrm{CO} 2(\mathrm{qCO} 2)$ as a specific activity parameter to assess the effects of environment conditions, such as $\mathrm{pH}$, on the microbial biomass of forest soils. Soil Biology \& Biochemistry, v.25, n.3, p.393-395, 1993.

CARDOSO, E.J.B.N.; VASCONCELLOS, R.L.F.; BINI, D. et al. Soil health: looking for suitable indicators. What should be considered to assess the effects of use and management on soil health? Scientia Agricola, v.70, n.4, p.274-289, 2013.

COSTA JR, C.; PÍCCOLO, M.C.; NETO, M.S. et al. Carbono em agregados do solo sob vegetação nativa, pastagem e sistemas agrícolas no bioma cerrado. Revista Brasileira de Ciência do Solo, v.36, n.4, p.1311-1321, 2012.

DEXTER, A.R.; CZYZ, E.A. Effects of soil management on the dispersibility of clay in a sandy soil. International Agrophysics, v.14, n.3, p.269-272, 2000.

DIAS, V.V.; SCHULTZ, G.; SCHUSTER, M.S. et al. O mercado de alimentos orgânicos: um panorama quantitativo e qualitativo das publicações internacionais. Ambiente \& Sociedade, v.18, n.1, p.161-182, 2015.

DUARTE, M.L.R.; LIMA, W.G.; CHU, E.Y. et al. Controle da podridão-das-raízes da pimenteira-doreino com diferentes bokashi. Belém: Embrapa Amazônia Oriental, 2006. 22p. (Embrapa Amazônia Oriental. Comunicado Técnico, 168). Available in: $<$ https://www.embrapa.br/amazonia-oriental/buscade-publicacoes/-/publicacao/ 889667/controlealternativo-da-podridao-das-raizes-da-pimenteirado-reino-com-microrganismos-eficazes-em $>$ Acess in: September, 21, 2016.
FERREIRA, S.; SOUZA, R.J.; GOMES, L.A.A. Produtividade de brócolis de verão com diferentes doses de bokashi. Revista Agrogeoambiental, v.5, n.2, p.31-38, 2013.

FUNDAÇÃO MOKITI OKADA - MOA. Microorganismos eficazes EM na agricultura. 2.ed. Ipeúna: FUNDAÇÃO MOKITI OKADA, 2002. 29p.

KASCHUK, G.; ALBERTON, O.; HUNGRIA, M. Three decades of soil microbial biomass studies in Brazilian ecosystems: lessons learned about soil quality and indications for improving sustainability. Soil Biology and Biochemistry, v.42, n.1, p.1-13, 2010.

KEMPER, W.D.; CHEPIL, W.S. Size distribution of aggregates. In: BLACK, C.A.; EVANS, D.D.; WHITE, J.L.; ENSMINGER, L.E. ; CLARK, F.E. Methods of soil analysis - Physical and mineralogical properties, including statistics of measurement and sampling. American Society of Agronomy, v.39, n.1, p.499-510, 1965.

MAGRINI, F.E.; CAMATTI-SARTORI, V.; FINKLER, R. et al. Características químicas e avaliação microbiológica de diferentes fases de maturação do biofertilizante. Agrarian, v.4, n.12, p.146-151, 2011.

MANDALAYWALA, H.P.; TRIVEDI, R. Effective microbial consortium of bacteria isolated from hydrocarbon polluted soils of Gujarat, India. Journal of Advanced Research in Biotechnology, v.1, n.1, p.1-9, 2016.

MAZURAK, A.P. Effect of gaseous phase on water-stable synthetic sand aggregates. Soil Science, v.69, n.2, p.135-148, 1950.

MOREIRA, F.M.S.; CARES, J.E.; ZANETTI, R.B. et al. In: . O ecossistema solo: componentes, relações ecológicas e efeitos na produção vegetal. Lavras: UFLA, p.13-30. 2013.

MOREIRA, F.M.S.; SIQUEIRA, J.O. Microbiologia e bioquímica do solo. 2.ed. Lavras: UFLA, 2006. 729p.

MOTA, N. F. Efeito do Bokashi no crescimento da cebolinha, do coentro e em alguns atributos químicos e biológicos do solo. Dissertação (Mestrado em Agronomia). Fortaleza, CE: UFC, 2013.66p. 
PAULA, F.S.; RODRIGUES, J.L.M.; ZHOU, J. et al. Lande use changes alters functional gene diversity, composition and abundance in Amazon forest soil microbial communities. Molecular Ecology, v.23, n.12, p.2988-2999, 2014.

PINDI, P.K.; SATYANARAYANA, S.D.V. Liquid Microbial Consortium - A Potential Tool for Sustainable Soil Health. Journal of Biofertilizers and Biopesticides, v.3, n.124, p.1-9, 2012.

POÇAS, E.C.; TEIXEIRA, E.M.; YADA, M.M. et al. Mineralização do $\mathrm{C}$ em solos submetidos à adição de diferentes tortas de oleaginosas. Synergismus Scyentifica, v.4, n.1, p.1-3, 2009.

POWLSON, D.S.; BROOKES, P.C.; CHRISTESEN, B.T. Measurement of soil microbial biomass provides an early indication of changes in total soil organic matter due to straw incorporation. Soil Biology \& Biochemistry, v.19, n.2, p.159-164, 1987.

RODRIGUES, J.L.M.; PELLIZARI, V.H.; MUELLER, $\mathrm{R}$. et al. Conversion of the Amazon rainforest to agriculture results in biotic homogenization of soil bacterial communities. Proceedings of the National Academy Sciences of the United States of America, v.110, n.3, p.988-993, 2013.
SAMPAIO, D.B.; ARAÚJO, A.S.F. de; SANTOS, V.B. Avaliação de indicadores biológicos de qualidade do solo sob sistemas de cultivo convencional e orgânico de frutas. Ciência e Agrotecnologia, v.32, n.2, p.353-359, 2008.

SILVA, E.E.; AZEVEDO, P.H.S.; DE-POLLI, H. Determinação da respiração basal (RBS) e quociente metabólico (qCO2). Seropédica: Embrapa Agrobiologia, 2007. 4p. (Embrapa Agrobiologia. Comunicado Técnico, 99). Available in: < http://www.infoteca.cnptia.embrapa.br/ handle/doc/627577> Acess in: August, 15, 2014.

SIQUEIRA, A.P.P.; SIQUEIRA, M.F.B. Bokashi: adubo orgânico fermentado. Niterói: Programa Rio Rural, 2013. 16p. (Programa Rio Rural. Manual Técnico; 40). Available in: <http:// www.pesagro.rj.gov.br/downloads/riorural/ 40_Bokashi_Adubo organico_fermentado.pdf> Acess in: August, 29, 2016.

VANCE, E.D.; BOOKES, P.C.; JENKINSON, D.S. An extraction method for measuring soil microbial biomass. Soil Biology \& Biochemistry, v. 19, n.6, p.703-707, 1987.

VORONEY, R.P.; The soil habitat. In: PAUL, E.A. (Eds.). Soil Microbiology, Ecology and Biochemistry. 3.ed. Oxford: Elsevier Academic Press, p.25-52. 2007. 